\title{
Analysis of caesarean sections according to Robson's criteria at a tertiary care teaching hospital in central India
}

\author{
Aparna Wahane, Ashwini S. Ghaisas*
}

Department of Obstetrics and Gynaecology, Government Medical College, Akola, Maharashtra, India

Received: 04 August 2020

Accepted: 09 September 2020

\section{*Correspondence:}

Dr. Ashwini S. Ghaisas,

E-mail: 03.ashwini@gmail.com

Copyright: (C) the author(s), publisher and licensee Medip Academy. This is an open-access article distributed under the terms of the Creative Commons Attribution Non-Commercial License, which permits unrestricted non-commercial use, distribution, and reproduction in any medium, provided the original work is properly cited.

\begin{abstract}
Background: The rate of caesarean section (CS) has been skyrocketed globally over the past three decades which makes it utmost essential to be reanalyzed. Hence, the Robson's classification of international standards has become a need of an hour. This study aimed to analyze the trend of caesarean sections at a tertiary care teaching hospital, by using Robson's criteria.

Methods: This cross-sectional observational study was conducted at Government Medical College in Akola. The data was collected for the women delivered by CS during November 2017 to April 2019 and proportions in various groups as per Robson's criteria were calculated.

Results: The overall CS rate for the study period at our hospital was 63.89\%. Robson Group $1(24.5 \%)$ had the greatest representation in the study population followed by Group 5 (21.27\%) and $3(14.18 \%)$. While Groups 6 $(10.13 \%)$ and $9(0.63 \%)$ had the least representation. Group 5 was found to be the highest absolute contributor $(20.5 \%)$ to overall CS rates followed by Group $1(16.08 \%)$. Group 9 had a least possible share in the study population, but it had $100 \%$ CS rate.

Conclusions: Robson's classification must be implemented in all delivery units to avoid unnecessary caesarean sections. Every effort should be made to provide caesarean sections to women in need, rather than striving to achieve a specific rate and Robson's criteria is a step forward in the same direction.
\end{abstract}

Keywords: Caesarean section, Robson's criteria

\section{INTRODUCTION}

High caesarean birth rate is an issue of international public health concern. The caesarean section (CS) rate has risen from 5\% in $1940-1950$ s to $15 \%$ in $1970-1980$ s. But during last 3 decades there has been a dramatic rise in CS rate worldwide which now exceeds $30 \%$ in some regions. ${ }^{1}$

In 1985, World health organization has recommended that CS rates should not be more than $15 \%$, as CS rates above this, are not associated with additional reduction in maternal neonatal mortality and morbidity. ${ }^{2}$ As with any surgery, CSs are associated with short-term and long- term risk which can extend many years beyond the current delivery and affect the health of the woman, her child, and future pregnancies. But over these last 3 decades, there has been a clear evidence of benefits vs risks of CS and marked improvements in the clinical obstetrics care outcomes have been observed. In view of this, there had been rising demand by the clinicians and health care policy makers to revisit the existing recommended rate proposed in $1985 .^{3}$

It was a challenge to determine an adequate CS rate in absence of a reliable and internationally accepted classification to get the standardized data enabling a global comparison. Hence, Dr. Michael Robson in 2001 
proposed the need to adopt standard classification system for easy comparison and improvement of obstetrics care and introduced Robson classification to achieve this. ${ }^{4}$ In 2015, The World Health Organization (WHO) and the International Federation of Gynecology and Obstetrics (FIGO) recommended Robson classification as a global standard for assessing, monitoring and comparing CS rates within heath care facilities, over time and between facilities. ${ }^{5,6}$

"Caesarean section rates should no longer be thought of as being too high or too low, but rather whether they are appropriate or not, after taking into consideration all the relevant information. ${ }^{4}$ " Dr. Michael Robson

Hence, the present study was conducted to analyze caesarean sections according to Robson's criteria (Robson's ten group classification system) in our setup which would help investigate the reasons for upward trend of CS rates in central India.

\section{METHODS}

Approval was obtained from the Institutional Review Board (IRB). This was a cross-sectional observational study conducted for a period of 18 months from November 2017 to April 2019 at Government Medical College, Akola, a tertiary care hospital in a rural area of the state of Maharashtra in Central India. All the women who underwent caesarean section in the institute during this period were included. A semi-structured questionnaire was used to collect all relevant obstetric information (parity, mode of previous deliveries, previous CS and indications, gestational age, onset of labor, spontaneous or induced labor, fetal presentation) and the data was entered into an excel chart on a monthly basis. Results were calculated at the end of 18 months. Percentages were calculated for the overall rate, the representation of the group's contribution of each group to the overall rate and percentage in each group. We used the Robson's ten group classification system (Table 1). ${ }^{7}$

Table 1: Robson's ten group classification system.

\begin{tabular}{|ll|}
\hline Robson groups & Description \\
\hline $\mathbf{1}$ & Nulliparous, single cephalic, $\geq 37$ weeks in spontaneous labour \\
\hline $\mathbf{2}$ & Nulliparous, single cephalic, $\geq 37$ weeks, induced or CS before labour \\
\hline $\mathbf{3}$ & Multiparous (excluding previous CS), single cephalic, $\geq 37$ weeks in spontaneous labour \\
\hline $\mathbf{4}$ & Multiparous (excluding previous CS), single cephalic, $\geq 37$ weeks, induced or CS before labour \\
\hline $\mathbf{5}$ & All multiparous with at least one previous CS, single cephalic, $\geq 37$ weeks \\
\hline $\mathbf{6}$ & All nulliparous, single breech \\
\hline $\mathbf{7}$ & All multiparous, single breech (including previous CS) \\
\hline $\mathbf{8}$ & All multiple pregnancies (including previous CS) \\
\hline $\mathbf{9}$ & All single, abnormal lies (including previous CS) \\
\hline $\mathbf{1 0}$ & All single cephalic, $<37$ weeks (including previous CS) \\
\hline
\end{tabular}

\section{RESULTS}

A total number of women delivered over a period were 1579. The total number of caesarean sections were 1009 . Hence, the overall caesarean section rate at our hospital was $63.89 \%$.
In our study, Robson groups 1 to 5 contributed the most to the study population $(80.78 \%)$, while groups 6 to 10 contributed $19.22 \%$ only. Robson groups 1 to 5 accounted for $76.31 \%$ to overall caesarean section rates, while Robson groups 6 to 10 accounted for $23.69 \%$ (Table 2).

Table 2: Rate of caesarean sections according to Robson classification in the study population.

\begin{tabular}{|lllllll|}
\hline $\begin{array}{l}\text { Rate of cesarean section according to Robson classification } \\
\text { Robson }\end{array}$ & $\begin{array}{l}\text { Total } \\
\text { CS }\end{array}$ & $\begin{array}{l}\text { Total } \\
\text { VD }\end{array}$ & $\begin{array}{l}\text { Total del } \\
\text { [CS+VD }\end{array}$ & $\begin{array}{l}\text { Rate of each } \\
\text { group }\end{array}$ & $\begin{array}{l}\text { Relative size in } \\
\text { each group }\end{array}$ & $\begin{array}{l}\text { Contribution of each } \\
\text { group to overall cs }\end{array}$ \\
\hline & {$[\mathrm{A}]$} & {$[\mathrm{C}]$} & {$[\mathrm{B}]$} & {$\left[\mathrm{A} / \mathrm{B}^{*} 100\right]$} & {$[\mathrm{B} / 1579 * 100]$} & {$[\mathrm{A} / 1579 * 100]$} \\
\hline $\mathbf{1}$ & 254 & 132 & 386 & 65.8 & 24.5 & 16.08 \\
\hline $\mathbf{2}$ & 133 & 36 & 169 & 78.6 & 10.7 & 8.42 \\
\hline $\mathbf{3}$ & 39 & 185 & 224 & 17.4 & 14.18 & 2.5 \\
\hline $\mathbf{5}$ & 20 & 140 & 160 & 12.5 & 10.13 & 1.26 \\
\hline $\mathbf{6}$ & 324 & 12 & 336 & 96.42 & 21.27 & 20.5 \\
\hline $\mathbf{7}$ & 27 & 1 & 28 & 96.4 & 1.77 & 1.7 \\
\hline $\mathbf{8}$ & 50 & 7 & 57 & 87.7 & 3.6 & 3.16 \\
\hline $\mathbf{9}$ & 37 & 10 & 47 & 78.72 & 2.97 & 2.34 \\
\hline $\mathbf{1 0}$ & 10 & 0 & 10 & 100 & 0.63 & 0.63 \\
\hline & 115 & 47 & 162 & 70.9 & 10.25 & 7.3 \\
\hline
\end{tabular}


Robson Group 1 (24.5\%) had the greatest representation in our population followed by Group $5(21.27 \%)$ and 3
(14.18\%). While Groups $6(10.13 \%)$ and $9(0.63 \%)$ had the least representation (Table 3 ).

Table 3: Ranking of Robson group according to group-wise contribution to the study population.

\begin{tabular}{|llll|}
\hline \multicolumn{2}{l}{ Ranking of group in order of representation } & Relative size in each group (\%) \\
\hline Rank & Robson group & 24.5 \\
\hline $\mathbf{1}$ & 1 & Nulliparous, single cephalic, $\geq 37$ weeks in spontaneous labour \\
\hline $\mathbf{2}$ & 5 & $\begin{array}{l}\text { All multiparous with at least one previous CS, single cephalic, } \\
\geq 37 \text { weeks }\end{array}$ & 21.27 \\
\hline $\mathbf{3}$ & 3 & $\begin{array}{l}\text { Multiparous (excluding previous CS), single cephalic, } \geq 37 \text { weeks } \\
\text { in spontaneous labour }\end{array}$ & 14.18 \\
\hline $\mathbf{4}$ & 2 & $\begin{array}{l}\text { Nulliparous, single cephalic, } \geq 37 \text { weeks, induced or CS before } \\
\text { labour }\end{array}$ & 10.7 \\
\hline $\mathbf{5}$ & 10 & All single cephalic, $<37$ weeks (including previous CS) & 10.25 \\
\hline $\mathbf{6}$ & 4 & $\begin{array}{l}\text { Multiparous (excluding previous CS), single cephalic, } \geq 37 \text { weeks, } \\
\text { induced or CS before labour }\end{array}$ & 10.13 \\
\hline $\mathbf{7}$ & 7 & All multiparous, single breech (including previous CS) & 3.6 \\
\hline $\mathbf{8}$ & 8 & All multiple pregnancies (including previous CS) & 2.97 \\
\hline $\mathbf{9}$ & 6 & All nulliparous, single breech & 1.77 \\
\hline $\mathbf{1 0}$ & 9 & All single, abnormal lies (including previous CS) & 0.63 \\
\hline
\end{tabular}

Table 4: Ranking of Robson group to overall caesarean section rate of the study population.

\section{Ranking of group to overall cs rates}

\begin{tabular}{llll} 
Rank & \multicolumn{2}{l}{ Robson group } & \multicolumn{1}{l}{$\begin{array}{l}\text { Relative size in each } \\
\text { group (\%) }\end{array}$} \\
\hline $\mathbf{1}$ & 5 & All multiparous with at least one previous CS, single cephalic, $\geq 37$ weeks & 20.5 \\
\hline $\mathbf{2}$ & 1 & Nulliparous, single cephalic, $\geq 37$ weeks in spontaneous labour & 16.08 \\
\hline $\mathbf{3}$ & 2 & Nulliparous, single cephalic, $\geq 37$ weeks, induced or CS before labour & 8.42 \\
\hline $\mathbf{4}$ & 10 & All single cephalic, $<37$ weeks (including previous CS) & 7.3 \\
\hline $\mathbf{5}$ & 7 & All multiparous, single breech (including previous CS) & 3.16 \\
\hline $\mathbf{6}$ & 3 & $\begin{array}{l}\text { Multiparous (excluding previous CS), single cephalic, } \geq 37 \text { weeks in } \\
\text { spontaneous labour }\end{array}$ & 2.5 \\
\hline $\mathbf{7}$ & 8 & All multiple pregnancies (including previous CS) & 2.34 \\
\hline $\mathbf{8}$ & 6 & All nulliparous, single breech & 1.7 \\
\hline $\mathbf{9}$ & 4 & $\begin{array}{l}\text { Multiparous (excluding previous CS), single cephalic, } \geq 37 \text { weeks, induced or } \\
\text { CS before labour }\end{array}$ & 1.26 \\
\hline $\mathbf{1 0}$ & 9 & All single, abnormal lies (including previous CS) & 0.63 \\
\hline
\end{tabular}

Table 5: Ranking of Robson group according to the rates in each group of the study population.

\begin{tabular}{|c|c|c|c|}
\hline Rank & Rol & 10 & $\begin{array}{l}\text { Rate of each } \\
\text { group }(\%)\end{array}$ \\
\hline 1 & 9 & All single, abnormal lies (including previous CS) & 100 \\
\hline 2 & 5 & All multiparous with at least one previous CS, single cephalic, $\geq 37$ weeks & 96.42 \\
\hline 3 & 6 & All nulliparous, single breech & 96.4 \\
\hline 4 & 7 & All multiparous, single breech (including previous CS) & 87.7 \\
\hline 5 & 8 & All multiple pregnancies (including previous CS) & 78.72 \\
\hline 6 & 2 & Nulliparous, single cephalic, $\geq 37$ weeks, induced or CS before labour & 78.6 \\
\hline 7 & 10 & All single cephalic, $<37$ weeks (including previous CS) & 70.9 \\
\hline 8 & 1 & Nulliparous, single cephalic, $\geq 37$ weeks in spontaneous labour & 65.8 \\
\hline 9 & 3 & $\begin{array}{l}\text { Multiparous (excluding previous CS), single cephalic, } \geq 37 \text { weeks in spontaneous } \\
\text { labour }\end{array}$ & 17.4 \\
\hline 10 & 4 & $\begin{array}{l}\text { Multiparous (excluding previous CS), single cephalic, } \geq 37 \text { weeks, induced or CS } \\
\text { before labour }\end{array}$ & 12.5 \\
\hline
\end{tabular}


Contribution to total caesarean section rates was highest by Group 5 (20.5\%) followed by Group 1 (16.08\%). Together these two groups contributed to more than half of the total caesareans and then came Groups $2(8.42 \%)$ and $10(7.3 \%)$. While Group 9 contributed the least i.e. $0.63 \%$ (Table 4). Percentage-wise Group 9 had the greatest i.e. $100 \%$ section rates. This means that all women in this group got delivered by CS. Followed by Group 5 and 6 which had $96.42 \%$ and $96.4 \%$ section rates respectively. Groups 4 and 3 had the least section rates $12.5 \%$ and $17.4 \%$ respectively, which means that many women got delivered vaginally (Table 5).

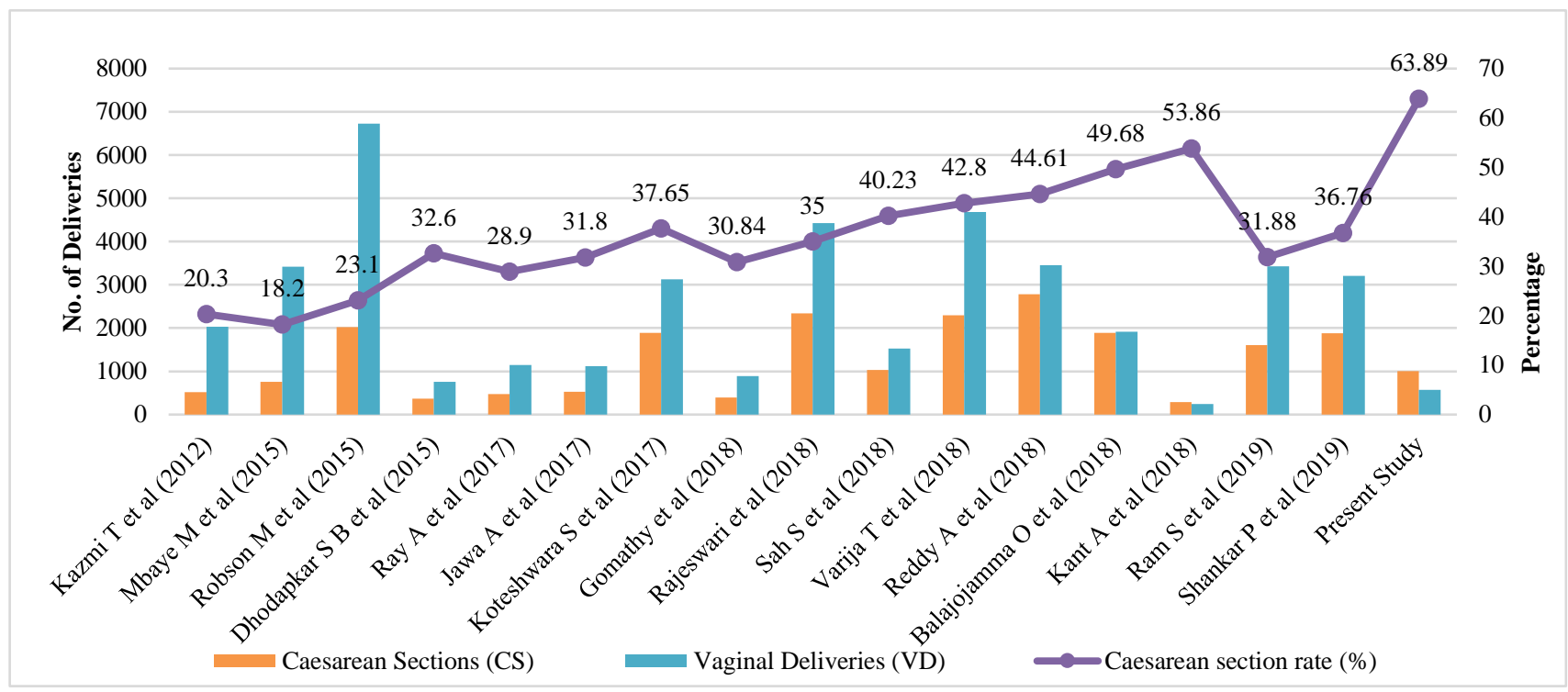

Figure 1: Comparison of total deliveries and rate of caesarean section of various studies.

\section{DISCUSSION}

In our study, out of 1579 deliveries, 1009 were caesarean sections and 570 were vaginal deliveries. The rate of caesarean section was $63.89 \%$. In Kant et al (2018) study, out of 531 deliveries, 286 were caesarean sections and 245 were vaginal deliveries while the rate of caesarean section was $53.86 \% .^{8}$ In all other studies stated above, vaginal deliveries were more in comparison to caesarean sections. Out of 16 studies, 7 studies had caesarean section rates ranging from $30 \%$ to $40 \%$ while 4 studies had rates between $40 \%$ to $50 \% .^{9-23}$ This explains the upward trend of caesarean sections.

Although WHO has proposed that at a population level caesarean section rates higher than $10 \%$ are not associated with reductions in maternal and newborn mortality rates, the rate of caesarean section in our hospital is quite higher $(63.89 \%)$. But our higher rates reflect the hospital section rate and not the population section rate. The reason for this high rate was probably because ours is a referral center which receives complicated pregnancies from the periphery.

This could be explained by the fact that even today, women in rural area have a lack of proper access to basic ANC care, lack of awareness of high-risk factors, lack of follow up for the same, lack of awareness about hospital delivery as well as development of unexpected complicating factors during delivery. Due to which, these women won't be able to seek timely care. There is also unavailability of operative delivery, ICU/NICU care and transfusion facilities at the primary booking center or other logistics.

In our study, Robson groups 1, 5 and 3 were found to be the major contributors of study population. Out of which, Robson groups 5 and 1 were found to be the largest absolute contributors (target groups) to overall CS rates. Though Robson group 9 was found to be the smallest contributor of study population and had a least share to overall CS rates, it had $100 \%$ CS rate within the group. This means that all the women in this group got delivered by caesarean section only. While group $5(96.42 \%)$ and group $6(96.4 \%)$ followed group 9 and group 4 had a least CS rate $(12.5 \%)$. The findings of which are well comparable to studies done nationally and internationally. ${ }^{10,13-15,17,22-24}$

Targeting group 5 (Multipara with at least one previous caesarean section) is of utmost importance as it was not only the largest absolute contributor of the study population but also of the overall caesarean section rates. Hence, adequate counselling for VBAC and its subsequent implementation should be exercised in selected low risk cases. Caesarean Delivery on Maternal Request (CDMR) should be discouraged in both the groups (with scar and without scar). Since the groups 1 and 3 are comprised of nullipara and multipara without previous caesarean section respectively, it is very much essential to follow ACOG/ SMFM clinical guidelines (March 2014, reaffirmed in 2019) to curtail primary caesarean delivery. ${ }^{25,26}$ 
Caesarean section can be reduced by optimal management in labour, appropriate use of augmentation, correct interpretation of fetal heart rate monitoring, trial of labour in case of nulliparous breech, operative vaginal deliveries, senior obstetrician involvement in decision making and use of confirmatory tests where fetal compromise is suspected. Unindicated induction of labour is also a matter of concern and hence it should be evidence-based and to be exercised in well indicated cases only.

\section{CONCLUSION}

The results of my study cannot be generalized as it is a single centered hospital based cross sectional study so it is possible that it may differ in some variables of the caesarean section. But it is well comparable to most studies done nationally and internationally as shown in the discussion.

The Robson 10-group classification system is easy to use and helps us to identify the target groups responsible for the rising trend of caesarean section. This helps us to reanalyze our protocols and to plan new strategies to reduce the caesarean section rates.

Hence, an internationally accepted classification i.e. Robson classification must be implemented in all delivery units to avoid unnecessary caesarean sections. Every effort should be made to provide caesarean sections to women in need, rather than striving to achieve a specific rate and Robson's classification is a step forward in the same direction.

\section{ACKNOWLEDGMENTS}

Authors would like to thank the staff of Department of Obstetrics and Gynecology, Government medical college, Akola, Maharashtra for their support during the study.

Funding: No funding sources

Conflict of interest: None declared

Ethical approval: The study was approved by the Institutional Ethics Committee

\section{REFERENCES}

1. Neonatal and Perinatal Mortality Country, Regional and Global Estimates. World Health Organization. 2006. Available from: https://apps.who.int/iris/handle/10665/43444. Accessed on 8 November 2019.

2. Ye J, Betrán AP, Vela MG, Souza JP, Zhang J. Searching for the optimal rate of medically necessary cesarean delivery. Birth. 2014;41:237-44.

3. Torloni MR, Betran AP, Souza JP, Widmer M, Allen T, Gulmezoglu M, et al. Classifications for cesarean section: A systematic review. PLoS One. 2011;6(1).
4. Robson MS. Can we reduce the caesarean section rate? Best Pract Res Clin Obstet Gynaecol. 2001;15(1):179-94.

5. WHO Statement on Caesarean Section Rates. 2015. Available at: https://apps.who.int/iris/bitstream/handle/10665/161 442/WHO_RHR_15.02_eng.pdf?sequence $=1$. Accessed on 10 November 2019.

6. Best practice advice on the 10-Group Classification System for cesarean deliveries. Int J Gynecol Obstet. 2016;135(2):232-3.

7. Goleman D, Boyatzis R, Mckee A. Robson Classification, Implementation manual. J Chem Inf Model. 2019;3:1689-99.

8. Kant A, Mendiratta S. Classification of cesarean section through Robson criteria: an emerging concept to audit the increasing cesarean section rate. Int $\mathbf{J}$ Reprod Contraception Obstet Gynecol. 2018;7(11):4674.

9. Mbaye M, Gueye M, Gueye M, Niang N, Moreau J. Analysis of cesarean section rate according to Robson's classification in an urban health centre in Senegal. Int $\mathrm{J}$ Reprod Contraception, Obstet Gynecol. 2015;4(4):1100-2.

10. Dhodapkar S, Bhairavi S, Daniel M, Chauhan N, Chauhan R. Analysis of caesarean sections according to Robson's ten group classification system at a tertiary care teaching hospital in South India. Int J Reprod Contraception, Obstet Gynecol. 2015;745-9.

11. Ray A, Jose S. Analysis of Caesarean-Section rates according to Robson's ten group classification system and evaluating the indications within the groups. Int J Reprod Contraception, Obstet Gynecol. 2017;6(2):447.

12. Koteshwara S, M. S. S. Analysis of caesarean section rates using Robsons ten group classification: the first step. Int J Reprod Contraception, Obstet Gynecol. 2017;6(8):3481.

13. Jawa A, Garg S, Bora T. Evaluation of Caesarean Section Rate Using Robson's 10 Group Classification in a Tertiary Care Centre. 2017;16(6):85-9.

14. Gomathy E. G, Radhika K, Kondareddy T. Use of the Robson classification to assess caesarean section trends in tertiary hospital. Int $\mathbf{J}$ Reprod Contraception, Obstet Gynecol 2018;7(5):1796.

15. Sah S, Goel R, Goel JK. Analysis of caesarean section rate according to Robson's criteria in tertiary care centre. Int J Reprod Contraception, Obstet Gynecol 2018;7(8):3060.

16. T. V, C. M. VK, Tarihalli C. Analysis of caesarean section rate in tertiary care hospital according to Robson`s 10 groups classification. Int J Reprod Contraception, Obstet Gynecol 2018;7(4):1380-4.

17. Reddy AY, Dalal A, Khursheed R. Robson ten group classification system for analysis of cesarean sections in an Indian hospital. Res $\mathbf{J}$ Obstet Gynecol 2018;11(1):1-8. 
18. Kazmi T, Sarva Saiseema V, Khan S. Analysis of cesarean section rate - according to robson's 10group classification. Oman Med J 2012;27(5):415-7.

19. Robson M, Murphy M, Byrne F. Quality assurance: The 10-Group Classification System (Robson classification), induction of labor, and cesarean delivery. Int J Gynecol Obstet 2015;131:S23-7.

20. Renukadevi OBMHN. One Year Study of Caesarean Section Rate in Govt. District Hospital with Robson TEN Group Classification. Int J Sci Res 2018;7(2):733-4.

21. Rajeswari, Parvathi S. Retrospective Analysis Of Caeserean Sections According To Robson's Classiffication System At A Tertiary Care Teaching Hospital In Telangana State. IOSR J Dent Med Sci 2018;17(2):26-9.

22. Shankar P, Raju V. A clinical study on the analysis of caesarean section rates using Robson's ten group classification in a tertiary care hospital. Int J Reprod Contraception, Obstet Gynecol 2019;8(2):488.

23. Ram S, Shaheen R, Gehlot N. Caesarean Section Rate Analysis According to Robson's Classification at Tertiary Centre. IOSR J Dent Med Sci 2019;18(9):11-4.
24. Vogel JP, Betrán AP, Vindevoghel N, Souza JP, Torloni MR, Zhang J, et al. Use of the robson classification to assess caesarean section trends in 21 countries: A secondary analysis of two WHO multicountry surveys. LancetGlob Heal. 2015;3(5): e260-70.

25. Safe Prevention of the Primary Cesarean Delivery. 2014. Available at: https://www.acog.org/ clinical/clinical-guidance/obstetric-careconsensus/articles/2014/03/safe-prevention-of-theprimary-cesarean-delivery. Accessed on 24 November 2019.

26. Caughey AB, Cahill AG, Guise JM, Rouse DJ. Safe prevention of the primary cesarean delivery. Am J Obstet Gynecol 2014;210(3):179-93.

Cite this article as: Wahane A, Ghaisas AS.

Analysis of caesarean sections according to Robson's criteria at a tertiary care teaching hospital in central India. Int J Reprod Contracept Obstet Gynecol 2020;9:4221-6. 